\title{
Front Matter: Volume 6758
}

, "Front Matter: Volume 6758," Proc. SPIE 6758, Photonics in the Transportation Industry: Auto to Aerospace, 675801 (9 October 2007); doi: $10.1117 / 12.775839$

SPIE. Event: Optics East, 2007, Boston, MA, United States 


\title{
PROCEEDINGS OF SPIE
}

\section{Photonics in the Transportation Industry: Auto to Aerospace}

\author{
Alex A. Kazemi \\ Christopher S. Baldwin \\ Editors \\ 10-11 September 2007 \\ Boston, Massachusetts, USA \\ Sponsored and Published by \\ SPIE
}

Volume 6758 
The papers included in this volume were part of the technical conference cited on the cover and title page. Papers were selected and subject to review by the editors and conference program committee. Some conference presentations may not be available for publication. The papers published in these proceedings reflect the work and thoughts of the authors and are published herein as submitted. The publisher is not responsible for the validity of the information or for any outcomes resulting from reliance thereon.

Please use the following format to cite material from this book:

Author(s), "Title of Paper," in Photonics in the Transportation Industry: Auto to Aerospace, edited by Alex A. Kazemi, Christopher S. Baldwin, Proceedings of SPIE Vol. 6758 (SPIE, Bellingham, WA, 2007) Article CID Number.

ISSN 0277-786X

ISBN 9780819469182

Published by

SPIE

P.O. Box 10, Bellingham, Washington $98227-0010$ USA

Telephone +1 3606763290 (Pacific Time) · Fax +1 3606471445

SPIE.org

Copyright (c) 2007, Society of Photo-Optical Instrumentation Engineers

Copying of material in this book for internal or personal use, or for the internal or personal use of specific clients, beyond the fair use provisions granted by the U.S. Copyright Law is authorized by SPIE subject to payment of copying fees. The Transactional Reporting Service base fee for this volume is $\$ 18.00$ per article (or portion thereof), which should be paid directly to the Copyright Clearance Center (CCC), 222 Rosewood Drive, Danvers, MA 01923. Payment may also be made electronically through CCC Online at copyright.com. Other copying for republication, resale, advertising or promotion, or any form of systematic or multiple reproduction of any material in this book is prohibited except with permission in writing from the publisher. The CCC fee code is $0277-786 \mathrm{X} / 07 / \$ 18.00$.

Printed in the United States of America.

Publication of record for individual papers is online in the SPIE Digital Library.

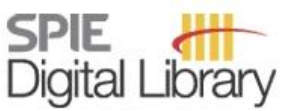

SPIEDigitalLibrary.org

Paper Numbering: Proceedings of SPIE follow an e-First publication model, with papers published first online and then in print and on CD-ROM. Papers are published as they are submitted and meet publication criteria. A unique, consistent, permanent citation identifier (CID) number is assigned to each article at the time of the first publication. Utilization of CIDs allows articles to be fully citable as soon they are published online, and connects the same identifier to all online, print, and electronic versions of the publication. SPIE uses a six-digit CID article numbering system in which:

- The first four digits correspond to the SPIE volume number.

- The last two digits indicate publication order within the volume using a Base 36 numbering system employing both numerals and letters. These two-number sets start with 00, 01, 02, 03, 04, 05, $06,07,08,09,0 \mathrm{~A}, 0 \mathrm{~B} \ldots \mathrm{OZ}$, followed by $10-1 \mathrm{Z}, 20-2 \mathrm{Z}$, etc.

The CID number appears on each page of the manuscript. The complete citation is used on the first page, and an abbreviated version on subsequent pages. Numbers in the index correspond to the last two digits of the six-digit CID number. 


\title{
Contents
}

\author{
$\checkmark$ Conference Committee \\ vii Introduction
}

\section{SESSION 1 OPTICAL SENSING TECHNOLOGY}

675802 Photonic sensor applications in transportation security [6758-01]

D. A. Krohn, Light Wave Venture LLC (USA)

675803 Bent tilted fiber Bragg gratings for temperature-independent vibration sensing in vehicles [6758-02]

A. Ivanov, J. Albert, Carleton Univ. (Canada)

675804 Ultrasound fiber guides and sensor applications [6758-03]

A. Safaai-Jazi, Virginia Polytechnic Institute and State Univ. (USA)

675805 Novel high resolution 2D optical shock and vibration sensor [6758-04]

B. Kress, A. Descoins, Applied Opto Technologies Inc. (USA)

675806 Optical waveguide pressure sensor using evanescent field [6758-05]

G. Kodl, Leoni AG (Germany)

675807 Fiber optic microsensor hydrogen leak detection system on Aerospike X-33 [6758-06] A. A. Kazemi, J. W. Goepp, The Boeing Co. (USA); D. B. Larson, M. E. Wuestling, NexGen Research Corp. (USA)

\section{SESSION 2 BRAGG GRATING SENSING}

675808 Fiber optic sensors monitoring transmission ring gears [6758-07]

C. Baldwin, J. Kiddy, Aither Engineering, Inc. (USA); P. Samuel, J. Coker, D. Pines, Univ. of Maryland, College Park (USA)

675809 Addressing fiber optic sensors limitations for aircraft applications [6758-08]

N. Mrad, Defence R\&D Canada (Canada)

6758 OA Compact and fast interrogation unit for fiber Bragg grating sensors [6758-09] P. Kiesel, M. Beck, O. Schmidt, N. Johnson, M. Bassler, Palo Alto Research Ctr. (USA); W. Ecke, K. Schroeder, H. Bartelt, Institute for Physical High-Technology (Germany)

$6758 \mathrm{OB}$ Miniature fiber Bragg grating sensor interrogator (FBG-Transceiver) system for use in aerospace and automotive health monitoring systems [6758-10]

E. A. Mendoza, C. Kempen, A. Panahi, Redondo Optics, Inc. (USA); C. Lopatin, Naval Surface Warfare Ctr. (USA) 
6758 OC Fiber optic oxygen sensor leak detection system for space applications [6758-1 1] A. A. Kazemi, The Boeing Co. (USA); K. Goswami, E. A. Mendoza, L. U. Kempen, Intelligent Optical Systems, Inc. (USA)

6758 OD An integrated optic hydrogen sensor for fast detection of hydrogen [6758-12] M. Z. Alam, J. Moreno, J. S. Aitchison, M. Mojahedi, Univ. of Toronto (Canada)

6758 OE Self-compensated high-speed FBG interrogation using closed-loop tracking system [6758-13]

L. U. Kempen, Intelligent Optical Systems, Inc. (USA); E. A. Mendoza, Redondo Optics, Inc. (USA); I. F. Saxena, Intelligent Optical Systems, Inc. (USA)

6758 OF Nanomaterial-based robust oxygen sensor [6758-14]

K. Goswami, U. Sampathkumaran, M. Alam, D. Tseng, A. K. Majumdar, InnoSense LLC (USA); A. A. Kazemi, Boeing Co. (USA)

6758 OG Inter-satellite communications using laser based optical links [6758-15]

A. S. Panahi, Redondo Optics, Inc. (USA); A. A. Kazemi, The Boeing Co. (USA)

\section{SESSION 4 VISION \& LIGHTING SYSTEMS}

$6758 \mathrm{OH} \quad 360^{\circ}$ vision system: opportunities in transportation [6758-16]

S. Thibault, ImmerVision (Canada)

6758 Ol Smart automotive bumper based on a multimode optical fiber [6758-17]

P. Meyrueis, B. Kress, Lab. des Systèmes Photoniques, Univ. Louis Pasteur (France); S. Fischer, PhoSyLab (France)

6758 0J High-precision investigations of the fast range imaging camera SwissRanger [6758-18] T. Kahlmann, H. Ingensand, ETH Zurich (Switzerland)

6758 OK A microstructure diffuser plate for LED lighting [6758-19]

C.-L. Lai, J.-S. Lin, Industrial Technology Research Institute (Taiwan); T. Yoshimi, Osaka Univ. (Japan); W.-H. Fan, Industrial Technology Research Institute (Taiwan)

Author Index 


\title{
Conference Committee
}

\author{
Symposium Chairs \\ Tuan Vo-Dinh, Duke University (USA) \\ Robert A. Lieberman, Intelligent Optical Systems, Inc. (USA) \\ Conference Chairs
}

Alex A. Kazemi, The Boeing Company (USA)

Christopher S. Baldwin, Aither Engineering, Inc. (USA)

Program Committee

Jacques Albert, Carleton University (Canada)

Kisholoy Goswami, InnoSense LLC (USA) and Intelligent Optical

Systems, Inc. (USA)

Harold E. Hager, The Boeing Company (USA)

Zuyuan He, The University of Tokyo (Japan)

Lothar U. Kempen, Intelligent Optical Systems, Inc. (USA)

Peter Kiesel, Palo Alto Research Center (USA)

David A. Krohn, Light Wave Venture Consulting, LLC (USA)

Edgar A. Mendoza, Redondo Optics, Inc. (USA)

Alan J. Rogers, University of Surrey (United Kingdom)

Ahmad Safaai-Jazi, Virginia Polytechnic Institute and State University (USA)

Session Chairs

1 Optical Sensing Technology

Alex A. Kazemi, The Boeing Company (USA)

2 Bragg Grating Sensing

Christopher S. Baldwin, Aither Engineering, Inc. (USA)

3 Fiber Optic Chemical Sensors

Jacques Albert, Carleton University (Canada)

Ahmad Safaai-Jazi, Virginia Polytechnic Institute and State University (USA)

$4 \quad$ Vision \& Lighting Systems

Alex A. Kazemi, The Boeing Company (USA) 
Downloaded From: https://www.spiedigitallibrary.org/conference-proceedings-of-spie on 26 Apr 2023

Terms of Use: https://www.spiedigitallibrary.org/terms-of-use 


\section{Introduction}

The field of fiber optic sensors has undergone a remarkable change over the past two decades. Today, a great proportion of the world's communications are carried by fiber optic cables. The fiber optics technology has revolutionized the telecommunications market and is rapidly becoming a major player in such areas as telephone, cable TV, and local-area network (LAN). It has spread into every situation in which information is being transmitted.

More information, intelligence, and data are transferred from one point to another, more quickly and precisely than ever thought possible, thanks to the miracle of optical fibers. As their algorithms and equations are developed and proved, fiber optics shall become as common as wire, easy to construct to precise tolerances, accurate and indefatigable in operation, and a type of circuit which enhances our lives and ways of living.

At the same time fiber optic sensor technology has developed in parallel with fiber optic and other optoelectronics industries such as lasers, which dominate the compact disk, DVD, laser printers, and scanner industries with the most promising uses for lasers and communications over fiber optic cable. In recent years, the fiber optic sensor greatly benefited from the low-cost telecommunications industries. Due to this synergy, an enormous amount of new technologies have been introduced in the form of smart sensors, biomedical sensors, microsensors, pressure, temperature, and liquid level, to name a few.

This book contains a series of papers which contains state-of-the-art fiber optic sensor technologies for photonics in transportation industries such as microsensors for cryogenic hydrogen and oxygen leak detection for space applications, to a new generation of fiber optic sensor using holography for detection of motion and vibration in automobile bumper shock, and finally a 360-degree vision system for transportation.

Alex A. Kazemi

Dedicated to my wife MARY \& late father KAMAL for their support throughout my life. 
Downloaded From: https://www.spiedigitallibrary.org/conference-proceedings-of-spie on 26 Apr 2023

Terms of Use: https://www.spiedigitallibrary.org/terms-of-use 